\title{
Editorial Volume 15 Issue 3
}

\section{Ciorstan Smark ${ }^{1}$ and Monir Mir ${ }^{2}$}

This issue of AABFJ brings together a range of articles from a variety of disciplines. From Accounting, Curran and Yapa (2021) look at the development of the taxation profession in Australia. They make interesting policy suggestions and recommend the establishment of a Tax Practitioners Board. Also related to accounting, Dasgupta (2021) studies the impact of individual corporate governance mechanisms in the 'paradoxical' risk-return association for Indian firms.

During a time of uncertainty Munoz, Todres and Rook (2021) look at organisational response to uncertainty and suggest the adoption of an antifragility strategy. Also, from the perspective of business, Wasiuzzaman (2021) presents a study based on the determinants of price and nonprice terms of bank loans made to Malaysian SMEs and the factors that appear to influence these terms. Also related to emerging markets, Dasgupta and Singh (2021) analyse the drivers of firm risk and managerial risk-taking in India.

Kangwa, Mwale and Shaikh (2021) present an interesting emerging markets study on the ability of Generation $\mathrm{Z}$ in Zambia to access digital finance and the implications of this. In an economic study, Wattankul, Nonthapot and Watchalaanun (2021) explore the factors influencing the competitiveness of the Thai processed pineapple export market.

In the area of most downloaded articles from AABFJ in the past few months, articles related to COVID-19 are downloading strongly. Gurbaxani and Gupte (2021) and Mittal and Sharma (2021) as well as Vinod and Sharma (2021) and Kuknor and Bhattacharya (2021) all appearing in the Most Popular Papers list for AABFJ. These papers have a geographical base in India.

Papers with a more diverse geographical and topic coverage are also downloading well. Finance is represented in the Most Popular Papers list with Reddy and Clinton (2016) and Buallay, Hamdan and Zureigat. A teaching study on finance, Hsing and Powell (2012) has also been amongst our top downloading articles since 2012. From Accounting and Financial Planning, Alam, Hassan, Bowyer and Reaz (2020) and Dewi, Febrian, Effendi and Anwar (2020) round out the Most Popular Papers list for AABFJ in the past three months.

\section{References}

Alam, Mohammad Nurul; Hassan, Md Mahmudul; Bowyer, Dorothea; and Reaz, Md, The Effects of Wages and Welfare Facilities on Employee Productivity: Mediating Role of Employee Work Motivation, Australasian Accounting, Business and Finance Journal, 14(4), 2020, 38-60. doi:10.14453/aabfj.v14i4.4

\footnotetext{
${ }^{1}$ University of Wollongong, Australia

${ }^{2}$ University of Canberra, Australia
} 
Buallay, Amina; Hamdan, Allam; and Zureigat, Qasim, Corporate Governance and Firm Performance: Evidence from Saudi Arabia, Australasian Accounting, Business and Finance Journal, 11(1), 2017, 78-98. doi:10.14453/aabfj.v11i1.6

Cheung, Yun Hsing and Powell, Robert J., Anybody can do Value at Risk: A Teaching Study using Parametric Computation and Monte Carlo Simulation, Australasian Accounting, Business and Finance Journal, 6(5), 2012, 101-118.

Dasgupta, Ranjan, Corporate Governance's Role in the Risk-Return Paradox - New Evidence from Indian Firms, Australasian Accounting, Business and Finance Journal, 15(3), 2021, 128-165. doi:10.14453/aabfj.v15i3.8

Dasgupta, Ranjan and Singh, Rashmi, Antecedents of Firm's Risk-play - A Structural Equation Modeling Approach in an Emerging Market Context, Australasian Accounting, Business and Finance Journal, 15(3), 2021, 67-94. doi:10.14453/aabfj.v15i3.5

Dewi, Vera; Febrian, Erie; Effendi, Nury; and Anwar, Mokhamad, Financial Literacy among the Millennial Generation: Relationships between Knowledge, Skills, Attitude, and Behavior, Australasian Accounting, Business and Finance Journal, 14(4), 2020, 2437. doi:10.14453/aabfj.v14i4.3

Gurbaxani, Arpita and Gupte, Rajani, A Study on the Impact of COVID- 19 on Investor Behaviour of Individuals in a Small Town in the State of Madhya Pradesh, India, Australasian Accounting, Business and Finance Journal, 15(1), 2021, 70-92. doi:10.14453/aabfj.v15i1.6

Kangwa, Diana; Mwale, Joseph Thokozani; and Shaikh, Junaid M., The Social Production of Financial Inclusion of Generation Z in Digital Banking Ecosystems, Australasian Accounting, Business and Finance Journal, 15(3), 2021, 95-118. doi:10.14453/aabfj.v15i3.6

Kuknor, Sunaina and Bhattacharya, Shubhasheesh, Organizational Inclusion and Leadership in Times of Global Crisis, Australasian Accounting, Business and Finance Journal, 15(1), 2021, 93-112. doi:10.14453/aabfj.v15i1.7

Mittal, Shivam and Sharma, Dipasha, The Impact of COVID-19 on Stock Returns of the Indian Healthcare and Pharmaceutical Sector, Australasian Accounting, Business and Finance Journal, 15(1), 2021, 5-21. doi:10.14453/aabfj.v15i1.2

Munoz, Albert; Todres, Mathew; and Rook, Laura, Empowering Organisations to Gain From Uncertainty: a Conceptualisation of Antifragility Through Leveraging Organisational Routines in Uncertain Environments, Australasian Accounting, Business and Finance Journal, 15(3), 2021, 23-42. doi:10.14453/aabfj.v15i3.3

Reddy, Krishna and Clinton, Vaughan, Simulating Stock Prices Using Geometric Brownian Motion: Evidence from Australian Companies, Australasian Accounting, Business and Finance Journal, 10(3), 2016, 23-47. doi:10.14453/aabfj.v10i3.3

Vinod, Paul P. and Sharma, Dipasha, COVID-19 Impact on the Sharing Economy PostPandemic, Australasian Accounting, Business and Finance Journal, 15(1), 2021, 37 50. doi:10.14453/aabfj.v15i1.4

Wasiuzzaman, Shaista, Determinants of the Price and Non-price Terms of Bank Loans: A Study of Malaysian SMEs, Australasian Accounting, Business and Finance Journal, 15(3), 2021, 43-66. doi:10.14453/aabfj.v15i3.4

Wattanakul, Thanet; Nonthapot, Sakkarin; and Watchalaanun, Tanawat, Factors Influencing the Processed Pineapple Export Competitiveness of Thailand, Australasian Accounting, Business and Finance Journal, 15(3), 2021, 119-127. doi:10.14453/aabfj.v15i3.7 